Hydrology and Earth System Sciences, 6(5), 833-848 (2002) C $\quad$ EGS

\title{
The impact of acid deposition and forest harvesting on lakes and their forested catchments in south central Ontario: a critical loads approach
}

\author{
S.A. Watmough and P.J. Dillon \\ ERS Program, Trent University, Peterborough, Ontario, Canada, K9J 7B8 \\ Email for corresponding author: swatmough@trentu.ca
}

\begin{abstract}
The impact of acid deposition and tree harvesting on three lakes and their representative sub-catchments in the Muskoka-Haliburton region of south-central Ontario was assessed using a critical loads approach. As nitrogen dynamics in forest soils are complex and poorly understood, for simplicity and to allow comparison among lakes and their catchments, CLs (A) for both lakes and forest soils were calculated assuming that nitrate leaching from catchments will not change over time (i.e. a best case scenario). In addition, because soils in the region are shallow, base cation weathering rates for the representative sub-catchments were calculated for the entire soil profile and these estimates were also used to calculate critical loads for the lakes. These results were compared with critical loads obtained by the Steady State Water Chemistry (SSWC) model. Using the SSWC model, critical loads for lakes were between 7 and $19 \mathrm{meq}^{-2} \mathrm{yr}^{-1}$ higher than those obtained from soil measurements. Lakes and forests are much more sensitive to acid deposition if forests are harvested, but two acid-sensitive lakes had much lower critical loads than their respective forested sub-catchments implying that acceptable acid deposition levels should be dictated by the most acid-sensitive lakes in the region. Under conditions that assume harvesting, the CL (A) is exceeded at two of the three lakes and five of the six sub-catchments assessed in this study. However, sulphate export from catchments greatly exceeds input in bulk deposition and, to prevent lakes from falling below the critical chemical limit, sulphate inputs to lakes must be reduced by between $37 \%$ and $92 \%$ if forests are harvested. Similarly, sulphate leaching from forested catchments that are harvested must be reduced by between 16 and $79 \%$ to prevent the ANC of water draining the rooting zone from falling below $0 \mu$ eq $\mathrm{l}^{-1}$. These calculations assume that extremely low calcium leaching losses $\left(9-27 \mu \mathrm{eq}^{-1}\right)$ from forest soils can be maintained without any decrease in forest productivity. Calcium concentrations in the three lakes have decreased by between $\sim 10$ and $25 \%$ over the past 20 years and calculations assume that calcium concentrations in lakes can fall to around $30 \%$ of their current values without any harmful effects on biota. Both these assumptions require urgent investigation.
\end{abstract}

Keywords: acid deposition, calcium, critical loads, forests, harvesting, lakes

\section{Introduction}

Critical loads are extensively used in Europe as the scientific basis upon which acceptable acid (sulphur, S and nitrogen, $\mathrm{N})$ deposition is calculated and preliminary studies have also been conducted in North America and Asia (Arp et al., 1996; Henriksen et al.,2002; Ouimet et al., 2001; Park and Lee, 2001; Posch et al., 2001). A critical load is defined as "a quantitative estimate of an exposure to one or more pollutants below which significant harmful effects on specified sensitive elements of the environment do not occur according to present knowledge" (Nilsson and Grennfelt, 1988). The most common methods for calculating steady state critical loads of acidity (CL A) are the Steady State Water Chemistry (SSWC) model for freshwaters and the
Simple Mass Balance (SMB) model for terrestrial systems (Posch et al., 2001).

The most recently published version of the SSWC model estimates the base cation (BC) weathering rate from the present day base cation flux and uses the so-called ' $\mathrm{F}$-factor' to account for part of the present base cation leaching because of ion exchange processes in soils (Henriksen and Posch, 2001). The buffer required to protect biota is represented by the $\mathrm{ANC}_{\text {limit }}$. In this study an $\mathrm{ANC}_{\text {limit }}$ of $40 \mu$ eq $1^{-1}$ was chosen to match that used by Henriksen et al. (2002) in CL calculations for $\sim 1500$ lakes in south central Ontario; this limit provides some degree of protection for aquatic biota. This model does not consider possible changes in nitrogen $(\mathrm{N})$ inputs to lakes and only considers present 
nitrate $\left(\mathrm{NO}_{3}\right)$ concentrations in lakes when calculating exceedance of the critical load. In contrast, the SMB model for forests can be calculated separately for sulphur (S) or for $\mathrm{S}+\mathrm{N}$. Estimates of base cation weathering rates and plant uptake rates are usually obtained directly from soil and forest measurements. The critical chemical limit $\left(\mathrm{ANC}_{\text {le(rit) }}\right)$ is usually a molar base cation $(\mathrm{BC})$ to aluminum $(\mathrm{Al})$ or calcium $(\mathrm{Ca})$ to $\mathrm{Al}$ ratio in soil solution that is considered non-toxic to trees (Cronan and Grigal, 1995).

In previous separate studies, both the SSWC and SMB models have been applied separately to lakes and forests respectively in south central Ontario. Henriksen et al. (2002) calculated that the majority of $\sim 1500$ lakes in south central Ontario currently have an exceedance of less than $20 \mathrm{meq}$ $\mathrm{m}^{-2} \mathrm{yr}^{-1}$. Arp et al. (1996) calculated that $\mathrm{S}+\mathrm{N}$ deposition exceeded the CL for terrestrial systems by up to $50 \mathrm{meq}$ $\mathrm{m}^{-2} \mathrm{yr}^{-1}$ in south central Ontario using the SMB model. This discrepancy leads to confusion as to what constitutes an acceptable level of acid deposition for south central Ontario: are forest soils more sensitive to acid deposition than lakes? This confusion arises because CL models for lakes and forests are designed to do essentially the same thing, but use different data sets and treat $\mathrm{N}$ inputs differently. In most regions this is necessary because the SMB model considers only weathering inputs in the rooting zone (usually $50 \mathrm{~cm}$ ), whereas the SSWC estimates base cation inputs to the lake via mineral weathering in the entire soil profile.

In the Muskoka-Haliburton region of south central Ontario, soils are generally thin (often $<1 \mathrm{~m}$ ) and if weathering rates for soils are calculated for the entire soil profile in addition to the rooting zone (Watmough and Dillon, 2002), CLs for lakes and forests can be calculated using the same data (uptake, mineral weathering, etc.). This approach also enables $\mathrm{BC}$ inputs predicted using the $\mathrm{F}$-factor in the SSWC model to be compared with BC inputs obtained from soil measurements. Furthermore, if $\mathrm{N}$ is treated in the same way in both models, a direct comparison of the sensitivity of lakes and forests to acid deposition can be made. In this study, a simple approach to the potential acidifying impact of $\mathrm{N}$ was used; it was assumed that current $\mathrm{NO}_{3}$ leaching losses will not change. Other models such as the First-order Acidity Balance (FAB) model could also be used to compare the acid sensitivity of lakes and forests as critical loads for S- and $\mathrm{N}$ - acidity are derived in the same way as in the SMB model. However, both the FAB model and the SMB model make assumptions about the long-term behaviour of $\mathrm{N}$ in soils that are poorly characterised. For simplicity, in this study, the sensitivity of lakes and forests to acid deposition was assessed using the most recent version of the SSWC model and a modified version of the SMB model, respectively. Clearly, if $\mathrm{N}$ leaching from forests increases due to climatic, management or deposition changes, the CL (A) for lakes and forests obtained in this study will be underestimated. The objectives of this study were threefold:

(1) To evaluate how CLs (A) for lakes obtained using the traditional SSWC model compare with CLs (A) values for lakes obtained from soil measurements.

(2) To evaluate the impact of harvesting on CL (A) estimates for both lakes and forests.

(3) To compare CLs (A) for lakes and their respective catchments to determine whether lakes are more sensitive to acid deposition than forests.

\section{Study area and input data}

The three headwater lakes (Plastic Lake, Chub Lake and Harp Lake) are located in the Muskoka-Haliburton region on a southern extension of the Precambrian Shield and represent a range of acid-sensitive lakes found in southcentral Ontario (Table 1). Bedrock mineralogy in the region is dominated by biotite gneiss with amphibolite present in some areas of Harp Lake. Upland soils are primarily orthic humo-ferric and ferro-humic podzols, formed from thin, sandy basal tills (Canadian Soil Survey, 1978). Upland forests in the region are dominated by uneven aged sugar maple (Acer saccharum Marsh.) and red maple (Acer rubrum L.), with lesser amounts of American beech (Fagus grandifolia Ehrh.), yellow birch (Betula alleghaniensis Britt.), red oak (Quercus rubra L.), eastern hemlock (Tsuga canadensis L.) and white pine (Pinus strobus L.) (Table 1).

The lakes are fed by between two (Chub Lake) and seven (Plastic Lake) streams that drain predominately upland, forested catchments. Because the stream chemistries of the major inflows to Chub Lake and Plastic Lake are similar, a single sub-catchment ( $\mathrm{PC} 1$ and $\mathrm{CB} 1$ respectively) is considered representative of the entire catchment of these lakes. In contrast, forest cover, soil depth, bedrock and slope differ among the sub-catchments of Harp Lake (Watmough and Dillon, 2002). As a result, the chemistry of the streams draining into Harp Lake differs considerably, and forest and soil data were therefore obtained from four of the subcatchments (HP3A, HP4, HP6 and HP6A). Based on the current stream water chemistry, these four sub-catchments are representative of the entire catchment draining into the lake. Deposition data were obtained from collections of bulk deposition, which is defined as that caught in a continuously open, $0.25 \mathrm{~m}^{2}$ collector, and were not corrected for sea-salt deposition because of the large distance from the nearest ocean. Input data for the SSWC model were obtained from lakewater chemistry measurements and annual runoff data 
Table 1. Some characteristics of the three lakes and their sub-catchments.

\begin{tabular}{|c|c|c|c|c|c|c|c|c|}
\hline Lakes & $\begin{array}{l}\text { Area } \\
\text { (ha) }\end{array}$ & $\begin{array}{l}\text { Volume } \\
\left(\mathrm{m}^{3} \times 10^{5}\right)\end{array}$ & $\begin{array}{l}\text { Mean Depth } \\
\text { (m) }\end{array}$ & $\begin{array}{l}\text { Maximum } \\
\text { (m) }\end{array}$ & epth & $\begin{array}{l}\text { Flushing rate } \\
\text { (years) }\end{array}$ & $p H$ & $\begin{array}{l}D O C \\
\left(m g l^{-1}\right)\end{array}$ \\
\hline Plastic Lake & 32.1 & 25.2 & 7.9 & 16.3 & & 2.68 & 5.5 & 2.0 \\
\hline Chub Lake & 34.4 & 30.4 & 8.9 & 27.0 & & 2.17 & 5.6 & 4.7 \\
\hline Harp Lake & 71.4 & 95.1 & 13.3 & 37.5 & & 3.39 & 6.3 & 3.6 \\
\hline Sub-Catchments & $\begin{array}{l}\text { Area } \\
\text { (ha) }\end{array}$ & $\begin{array}{l}\% \text { minor till } \\
(>1 \mathrm{~m})\end{array}$ & $\begin{array}{l}\% \text { thin till, } \\
\text { rock ridges }\end{array}$ & $\begin{array}{l}\% \text { pond, } \\
\text { bedrock }\end{array}$ & $\%$ peat & $\begin{array}{l}\text { Basal area } \\
\quad\left(m^{2} h a^{-1}\right)\end{array}$ & \multicolumn{2}{|c|}{$\begin{array}{l}\text { Dominant } \\
\text { tree species }\end{array}$} \\
\hline PC1 & 23.3 & 9.6 & 80.2 & 3.2 & 7.0 & 31.3 & \multicolumn{2}{|c|}{ WP, HE } \\
\hline CB1 & 59.7 & 24.2 & 72.4 & 0.6 & 2.8 & 26.2 & \multicolumn{2}{|c|}{ RM, SM, RO } \\
\hline HP3A & 19.9 & 97.1 & 0 & 0 & 2.9 & 21.3 & \multicolumn{2}{|c|}{ SM, YB } \\
\hline HP4 & 119.1 & 56.1 & 32.8 & 0.9 & 0 & 23.5 & \multicolumn{2}{|c|}{ SM, RM } \\
\hline HP6 & 10.0 & 45.2 & 54.8 & 0 & 0 & 24.0 & \multicolumn{2}{|c|}{ SM, YB } \\
\hline HP6A & 15.3 & 6.6 & 84.9 & 0 & 8.5 & 23.8 & \multicolumn{2}{|c|}{ SM, HE, YB } \\
\hline
\end{tabular}

(Henriksen et al., 2002). Data for the SMB model and weathering estimates for the entire soil profile were obtained from forest and soil measurements conducted in 1999/2000 at the six sub-catchments (Watmough and Dillon, 2002).

\section{Critical load calculations}

\section{LAKES - SSWC (USING TRADITIONAL METHOD OF ESTIMATING PRE-INDUSTRIAL BASE CATION INPUTS; $\mathrm{BC}_{\mathrm{O}}$ )}

Critical loads of acidity for surface waters were calculated using the most recent published description of the SSWC model (Henriksen and Posch, 2001; Henriksen et al., 2002);

$$
\mathrm{CL}(\mathrm{Ac})=\mathrm{BC}_{\mathrm{o}}-\mathrm{ANC}_{\text {limit }}
$$

Where $\mathrm{CL}(\mathrm{Ac})$ is the critical load of acidity; $\mathrm{BC}_{\mathrm{o}}$ represents the pre-industrial $\mathrm{BC}$ inputs $\left(\mathrm{BC}_{\mathrm{w}}+\mathrm{BC}_{\text {dep }}-\mathrm{BC}_{\mathrm{u}}\right)$ into lakes. $\mathrm{BC}_{\mathrm{w}}$ is base cation $(\mathrm{BC}=\mathrm{Ca}+\mathrm{Mg}+\mathrm{K}+\mathrm{Na})$ weathering, $\mathrm{BC}_{\text {dep }}$ is base cation deposition, $\mathrm{BC}_{\mathrm{u}}$ is base cation uptake (note $\mathrm{BC}$ in this instance is only $\mathrm{Ca}+\mathrm{Mg}+\mathrm{K}$ ) and $\mathrm{ANC}_{\text {limit }}$ is the buffer required to protect biota in lakes. All parameters are expressed as annual fluxes (meq $\mathrm{m}^{-2} \mathrm{yr}^{-1}$ ). In this study, ANC is defined as $(2[\mathrm{Ca}]+2[\mathrm{Mg}]+[\mathrm{K}]+[\mathrm{Na}])-\left(2\left[\mathrm{SO}_{4}\right]\right.$ $\left.-\left[\mathrm{NO}_{3}\right]-[\mathrm{Cl}]\right)$. In this study, it was assumed that all the $\mathrm{Cl}$ was of anthropogenic origin and $\mathrm{Cl}$ deposition $(3.9 \mathrm{meq}$ $\mathrm{m}^{-2} \mathrm{yr}^{-1}$ ) was included when calculating exceedance of the critical load (see Eqn. 2). In addition, at Harp Lake, where road salt contamination has occurred in recent years, the mean Na concentration measured between 1980 and 1985 (prior to road salt application) was used to calculate CLs. Mean $\mathrm{Na}$ and $\mathrm{Cl}$ concentrations measured in 1980-1985 were also used to calculate the current (1995-1999) ANC of the lake.

Traditionally, $\mathrm{NO}_{3}$ is included only when calculating present exceedance of the critical load for acidity:

$$
\mathrm{Ex}(\mathrm{Ac})=\mathrm{S}_{\text {dep }}+\mathrm{N}_{\text {leach }}+\mathrm{Cl}_{\text {dep }}-\mathrm{CL}(\mathrm{Ac})
$$

Where $\mathrm{Cl}_{\text {dep }}$ represents $\mathrm{Cl}$ deposition $\left(\right.$ meq $\mathrm{m}^{-2} \mathrm{yr}^{-1}$ ) and $\mathrm{N}_{\text {leach }}$ represents the $\mathrm{NO}_{3}$ concentration in the lake expressed as meq $\mathrm{m}^{-2} \mathrm{yr}^{-1}$.

However, to allow a direct comparison of CLs between lakes and their catchments, for simplicity, it was assumed that $\mathrm{NO}_{3}$ input into lakes over time is constant, driven primarily by physical and chemical processes in the forested catchments.

$$
\mathrm{CL}(\mathrm{A})=\mathrm{CL}(\mathrm{Ac})-\mathrm{N}_{\text {leach }}-\mathrm{Cl}_{\text {dep }}
$$

Therefore in this study CL (A) is calculated assuming that $\mathrm{N}$ leaching will not change over time and as current $\mathrm{NO}_{3}$ concentrations in the lakes are low, these calculations represent the 'best-case' scenario. Nitrate values were obtained from the long-term (1980-1998) average lake concentration and annual runoff.

Further details of the SSWC model are given by Henriksen and Posch (2001) and Henriksen et al. (2002). Briefly, the model uses current base cation concentrations in lakes to 
estimate the $\mathrm{BC}$ inputs in pre-industrial times $\left(\mathrm{BC}_{\mathrm{o}}\right)$ using the so-called F-factor.

$$
[\mathrm{BC}]_{0}=[\mathrm{BC}]_{\mathrm{t}}-\mathrm{F} \times\left(\left[\mathrm{SO}_{4}\right]_{\mathrm{t}}+\left[\mathrm{NO}_{3}\right]_{\mathrm{t}}-\left[\mathrm{SO}_{4}\right]_{0}-\left[\mathrm{NO}_{3}\right]_{0}\right)
$$

where the subscripts 0 and $t$ refer to pre-acidification and present concentrations, respectively; $\left[\mathrm{SO}_{4}\right]_{0}$ is estimated from a linear regression with $[\mathrm{BC}]_{\mathrm{t}}$ and $\left[\mathrm{NO}_{3}\right]_{0}$ is assumed to be zero. The F-factor represents the fraction of present base cations in lakes due to soil acidification:

$$
\mathrm{F}=\sin \left(\frac{\frac{\pi}{2} \times \mathrm{Q} \times[\mathrm{BC}]_{\mathrm{t}}}{\mathrm{S}}\right)
$$

where $\mathrm{S}$ is the base cation flux at which $\mathrm{F}=1$. For Norway $\mathrm{S}$ has been estimated to be $400 \mathrm{meq} \cdot \mathrm{m}^{-2} \cdot \mathrm{yr}^{-1}$. If $\mathrm{Q} \times[\mathrm{BC}]_{\mathrm{t}}>$ 400 , then $\mathrm{F}$ is set to 1 .

$\left[\mathrm{SO}_{4}^{2-}\right]_{0}$ is estimated from the relationship between $\left[\mathrm{SO}_{4}{ }^{2-}\right]_{\mathrm{t}}$ and $[\mathrm{BC}]_{\mathrm{t}}$ for lakes in regions little affected by acid deposition. For Norway, the following relationship exists (Henriksen and Posch, 2001):

$$
\left[\mathrm{SO}_{4}\right]_{0}=8+0.17 \times[\mathrm{BC}]_{\mathrm{t}}
$$

This equation suggests that there is an atmospheric background contribution of $\left[\mathrm{SO}_{4}\right]$ equal to $8 \mu \mathrm{eq} \cdot \mathrm{L}^{-1}$ and a geological contribution, proportional to the concentration of base cations. Equations 5 and 6 have previously been deemed appropriate for south-central Ontario (Henriksen and Dillon, 2001; Henriksen et al., 2002).

\section{LAKES - SSWC (USING BC INPUTS FROM}

WEATHERING ESTIMATES FOR THE ENTIRE SOIL PROFILE OF REPRESENTATIVE SUB-CATCHMENTS)

To calculate the CL (A) for lakes using soil base cation weathering estimates, base cation inputs to the lake from the terrestrial ecosystem $\left(\mathrm{BC}_{\mathrm{w}}+\mathrm{BC}_{\mathrm{dep}}-\mathrm{BC}_{\mathrm{u}}\right)$ were calculated assuming no net forest growth (no harvesting) and also under conditions that assume a stem-only harvest, weighted by the area of the terrestrial catchment. Input data were obtained from soil and forest measurements in selected representative sub-catchments of the three lakes (Table 1; Watmough and Dillon, 2002). Weathering inputs ( $\mathrm{Zr}$ depletion) from the entire soil profile were used in these calculations (Table 2). Atmospheric base cation inputs to the lake were obtained from bulk deposition measurements weighted by the area of the lake. Once base cation inputs $\left(\mathrm{BC}_{\mathrm{o}}\right)$ into the lakes were calculated, critical loads for acidity were calculated as for the SSWC model (Eqns. 1 and 3).

\section{Forest soils}

Critical loads for $\mathrm{S}$ for terrestrial systems are typically calculated using the SMB model:

$$
\mathrm{CL}(\mathrm{S})=\mathrm{BC}_{\mathrm{w}}+\mathrm{BC}_{\mathrm{dep}}-\mathrm{Cl}_{\text {dep }}-\mathrm{BC}_{\mathrm{u}}-\mathrm{ANC}_{\text {le(crit) }}
$$

Critical loads for acidity $(\mathrm{S}+\mathrm{N})$ are usually calculated as:

$$
\begin{aligned}
\mathrm{CL}(\mathrm{S}+\mathrm{N})= & \mathrm{BC}_{\mathrm{dep}}+\mathrm{BC}_{\mathrm{w}}-\mathrm{BC}_{\mathrm{u}}-\mathrm{Cl}_{\mathrm{dep}}+\mathrm{N}_{\mathrm{i}}+\mathrm{N}_{\mathrm{u}} \\
& +\mathrm{N}_{\mathrm{de}}-\mathrm{ANC}_{\mathrm{le}(\text { crit })}
\end{aligned}
$$

\begin{tabular}{|c|c|c|c|c|c|c|c|c|}
\hline & \multicolumn{2}{|c|}{ Soil pH $\left(\mathrm{CaCl}_{2}\right)$} & \multirow{2}{*}{$\begin{array}{l}E x-C a \\
\left(k e q h a^{-1}\right)\end{array}$} & \multirow{2}{*}{$\begin{array}{l}E x-M g \\
\left(k e q h a^{-1}\right)\end{array}$} & \multirow{2}{*}{$\begin{array}{l}E x-K \\
\left(k e q h a^{-1}\right)\end{array}$} & \multicolumn{2}{|c|}{ Base cation weathering } & \multirow{2}{*}{$\begin{array}{l}\mathrm{NO}_{3} \\
\text { leaching } \\
\left(\text { meq } m^{-2} y r^{-1}\right)\end{array}$} \\
\hline & A-horizon & B-horizon & & & & $\left(\right.$ meq $\left.m^{-2} y r^{-1}\right)$ & $\begin{array}{l}\text { soil profile } \\
\left(\text { meq } m^{-2} y r^{-1}\right)\end{array}$ & \\
\hline $\mathrm{PC} 1$ & 3.1 & 4.1 & 5.7 & 2.3 & 2.6 & 36.5 & 36.5 & 0.7 \\
\hline CB1 & 3.4 & 4.4 & 28.5 & 6.5 & 7.7 & 41.4 & 59.8 & 1.1 \\
\hline HP3A & 4.1 & 4.4 & 66.8 & 11.8 & 10.6 & 54.8 & 97.4 & 7.7 \\
\hline HP4 & 3.5 & 4.3 & 41.5 & 8.2 & 6.1 & 73.0 & 128.5 & 4.0 \\
\hline HP6 & 3.5 & 4.3 & 30.8 & 7.7 & 10.0 & 42.1 & 84.4 & 10.2 \\
\hline HP6A & 3.6 & 4.2 & 40.4 & 8.7 & 6.2 & 49.4 & 70.7 & 1.1 \\
\hline
\end{tabular}

where $\mathrm{N}_{\mathrm{i}}=$ net nitrogen immobilization rate in soil (meq $\mathrm{m}^{-}$

Table 2. Selected chemical characteristics of the seven sub-catchments and base cation weathering rates used in the SMB critical load calculations. 
$\left.{ }^{2} \mathrm{yr}^{-1}\right) ; \mathrm{N}_{\mathrm{u}}=$ net nitrogen uptake (meq $\left.\mathrm{m}^{-2} \mathrm{yr}^{-1}\right) ; \mathrm{N}_{\mathrm{de}}=$ net denitrification rate $\left(\mathrm{meq} \mathrm{m} \mathrm{rr}^{-1}\right)$ and $\mathrm{ANC}_{\text {le(rit) }}=$ critical alkalinity leaching rate. However, $\mathrm{NO}_{3}$ export from subcatchments in our region is unrelated to deposition, $\mathrm{N}_{\mathrm{i}}$ and $\mathrm{N}_{\mathrm{de}}$ are unknown and $\mathrm{NO}_{3}$ export can vary ten-fold between sub-catchments and between years (Watmough and Dillon, 2002). Therefore, a more appropriate way of calculating current exceedance of the critical load for acidity for forest soils is:

$$
\operatorname{Ex}(A)=\mathrm{S}_{\text {dep }}+\mathrm{N}_{\text {leach }}-\mathrm{CL}(\mathrm{S})
$$

If $\mathrm{N}$ leaching is assumed not to change over time, then:

$$
\mathrm{CL}(\mathrm{A})=\mathrm{CL}(\mathrm{S})-\mathrm{N}_{\text {leach }}
$$

As CL (A) for forest soils (Eqn. 10) and CL (A) for lakes (Eqn. 3) are both essentially calculating net base cation inputs into the system, critical loads of acidity (CL A) for forest soils and lakes can be compared directly. $\mathrm{N}_{\text {leach }}$ values were obtained from the long-term (1982-1999) average annual runoff from the seven catchments (Table 2). In the case of the $\mathrm{SMB}$ model, the $\mathrm{ANC}_{\text {le(crit) }}$ is typically set according to a critical $\mathrm{BC}: \mathrm{Al}$ (or $\mathrm{Ca}: \mathrm{Al}$ ) in soil solution that is considered damaging to trees (Cronan and Grigal, 1995). However, Watmough and Dillon (2002d) suggested that BC limitation was potentially much more damaging to trees than $\mathrm{Al}$ toxicity in the study region and recommended setting $\mathrm{ANC}_{\text {le(crit) }}$ equal to 0. In this study therefore, $\mathrm{ANC}_{\text {le(rrit) }}$ was set to 0 in critical load calculations for forest soils, although the implication of setting such a conservative critical chemical criterion is discussed.

\section{Results and discussion}

\section{COMPARING CRITICAL LOADS OF ACIDITY FOR \\ LAKES CALCULATED BY THE SSWC MODEL WITH \\ VALUES OBTAINED FROM SOIL MEASUREMENTS}

In this study, critical loads estimated by the SSWC model (F-factor) were compared directly with those predicted from forest and soil measurements. Critical loads of acidity were between 6.7 and $18.7 \mathrm{meq} \mathrm{m}^{-2} \mathrm{yr}^{-1}$ higher using $\mathrm{BC}_{\mathrm{o}}$ estimates calculated using the SSWC model compared with $\mathrm{BC}_{\mathrm{o}}$ values obtained from soil measurements in the representative sub-catchments (Table 3). Critical loads of acidity for the three lakes were between $39.0 \mathrm{meq} \mathrm{m}^{-2} \mathrm{yr}^{-1}$ (Plastic Lake) and $84.1 \mathrm{meq} \mathrm{m}^{-2} \mathrm{yr}^{-1}$ (Harp Lake) using the SSWC model compared with $20.3 \mathrm{meq} \mathrm{m}^{-2} \mathrm{yr}^{-1}$ (Plastic Lake) and $67.5 \mathrm{meq} \mathrm{m}^{-2} \mathrm{yr}^{-1}$ (Harp Lake) using $\mathrm{BC}_{\mathrm{o}}$ estimates obtained from soil measurements. Critical load estimates from the SSWC model indicate that the CL (A) is currently exceeded (S bulk deposition $\sim 40 \mathrm{meq}^{-2} \mathrm{yr}^{-1}$ ) at Plastic Lake only. Although these differences in critical load estimates obtained using the two estimates of $\mathrm{BC}_{\mathrm{o}}$ in the SSWC model are relatively small, a discrepancy of $19 \mathrm{meq}$ $\mathrm{m}^{-2} \mathrm{yr}^{-1}$ is equal to approximately half of the current bulk S deposition in this region. There is clearly a need to be more precise in the critical load estimates in this region.

\section{MAJOR DISCREPANCIES IN THE ESTIMATION OF $\mathrm{BC}_{\mathrm{O}}$ USING THE TRADITIONAL METHOD AND DIRECT ESTIMATES FROM SOIL MEASUREMENTS FOR CALCULATING CLs FOR LAKES}

Several possibilities may account for the discrepancy in $\mathrm{BC}_{\mathrm{o}}$ between the two approaches, but inconsistencies in $\mathrm{S}$

Table 3. Critical loads of acidity for Plastic Lake, Chub Lake, Harp Lake and their catchments.

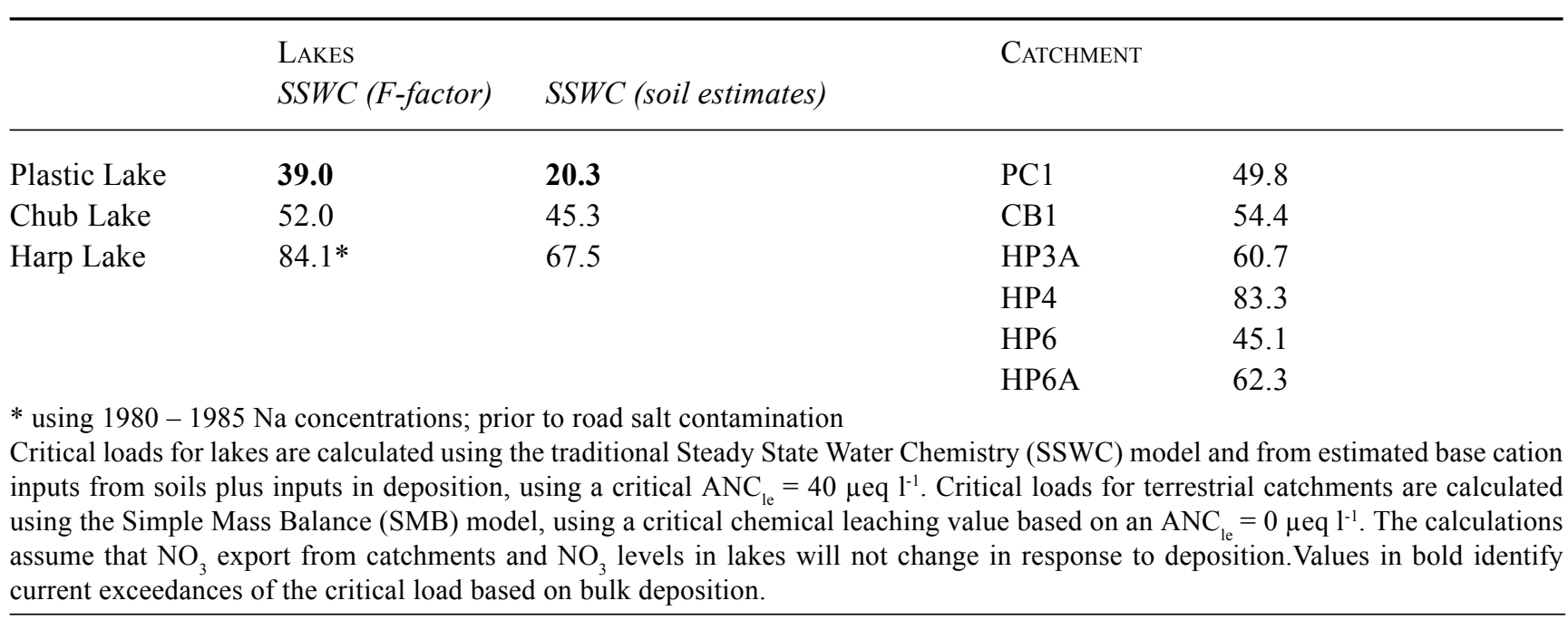


weathering inputs assumed by the two methods represent a fundamental difference in the SSWC and the SMB models. Traditionally, the SSWC model calculates the increase in acid anions by calculating the pre-industrial level of $\mathrm{SO}_{4}$ in the lake (Eqn. 6). In this study, pre-industrial $\mathrm{SO}_{4}$ was calculated using the relationship of Brakke et al. (1989), which Henriksen et al. (2002) considered to be applicable to Ontario lakes. This implies that in the study region where $\mathrm{BC}$ inputs in deposition are low and relatively consistent, approximately $17 \mathrm{meq}^{-2} \mathrm{yr}^{-1}$ of $\mathrm{S}$ is released by weathering for every $100 \mathrm{meq} \mathrm{m}^{-2} \mathrm{yr}^{-1}$ increase in $\mathrm{BC}$ weathering. These weathering rates are much higher than would be expected from acid podzols with low $\mathrm{S}$ contents (Houle and Carignan, 1995). For example, at $\mathrm{PC} 1$ which has a $\mathrm{BC}$ weathering rate of $36.5 \mathrm{meq} \mathrm{m}^{-2} \mathrm{yr}^{-1}$, approximately $6.2 \mathrm{meq} \mathrm{m}^{-2} \mathrm{yr}^{-1} \mathrm{~S}$ would be released by mineral weathering, even though $\mathrm{S}$ concentrations in bedrock at PC1 are only $\sim 100 \mathrm{mg} \mathrm{kg}^{-1}$ (Kirkwood, 1990). However, because pre-industrial $\left[\mathrm{SO}_{4}\right]$ is actually calculated from current $\mathrm{BC}$ concentrations in lakes, and the average (1995-99) BC concentration in Plastic Lake is $137 \mu$ eq $\mathrm{l}^{-1}$, the $\mathrm{S}$ weathering input to Plastic Lake assumed by the SSWC model is approximately $11.6 \mathrm{meq}$ $\mathrm{m}^{-2} \mathrm{yr}^{-1} \mathrm{~S}$. This could account for a significant proportion of the net $\mathrm{S}$ export observed in forested catchments in this region (Eimers and Dillon, 2002). Furthermore, if $\mathrm{S}$ weathering rates are so high, then $\mathrm{S}_{\mathrm{w}}$ should be included in the CL for forest soils.

\section{THE IMPACT OF HARVESTING ON CRITICAL LOAD}

\section{ESTIMATES FOR LAKES}

According to Eqn. (1), base cation uptake by trees is considered in the SSWC model when determining preindustrial base cation inputs if there is currently net base cation uptake. Therefore, it may be argued that the impact of selective harvesting in this region should already be taken into account using the traditional SSWC model because most forests in this region are actively growing. However, if CLs for lakes are calculated during a period when there is no net growth (forest is at steady state) and then there is a harvest - the base cation removal should be included in the SSWC model. Indeed, Henriksen and Posch (2001) stated that "if there is a change in the net uptake due to changes in management practices, this has to be taken into account". Therefore, although the impact of harvesting should be considered in the critical load calculations for lakes, in practice it is rarely done, primarily because of the ambiguity regarding how harvest removals should be treated in the SSWC model.

If harvest removals are included in the critical load calculations for lakes, much lower CLs (A) $(\sim 20 \mathrm{meq}$ $\mathrm{m}^{-2} \mathrm{yr}^{-1}$ ) for the three lakes are obtained (Table 4; Figs. 13). The CL (A) for the three lakes are between $22.3 \mathrm{meq}$ $\mathrm{m}^{-2} \mathrm{yr}^{-1}$ (Plastic) and $59.6 \mathrm{meq} \mathrm{m}^{-2} \mathrm{yr}^{-1}$ (Harp) using the SSWC model and are between $3.6 \mathrm{meq} \mathrm{m}^{-2} \mathrm{yr}^{-1}$ (Plastic) and 43.0 meq $\mathrm{m}^{-2} \mathrm{yr}^{-1}$ (Harp) using $\mathrm{BC}_{\mathrm{o}}$ estimates from soil measurements. As a result of including a harvest removal in the calculations, the CL (A) is exceeded at both Plastic Lake and Chub Lake. It is therefore extremely important to determine whether harvest removals need to be subtracted when calculating CLs using the traditional SSWC model.

In an attempt to assess more accurately whether harvesting removals are included in the SSWC model, net BC uptakes (calculated between 1983 and 1999) from two subcatchments (HP4 and PC1) were considered. At PC1 there was no net $\mathrm{BC}$ uptake by the forest during the 17-year period (Watmough and Dillon, 2002). If net BC uptake had occurred at $\mathrm{PC} 1$, current $\mathrm{BC}$ concentrations in the lake would be lower (current exchangeable $\mathrm{BC}$ pool in soil is very low) due to lower runoff concentrations so that a different (much lower) CL would have been obtained using the traditional SSWC model. As a result, if harvesting were to occur at Plastic

Table 4. Critical loads for acidity for Plastic Lake, Chub Lake, Harp Lake and their catchments, under conditions that assume stem-only harvesting (see Table 3 for further explanation).

\begin{tabular}{lllll}
\hline & LAKe & & CATCHMENT & \\
& SSWC (F-factor) & SSWC (soil estimates) & \\
\hline Plastic Lake & $\mathbf{2 2 . 3}$ & $\mathbf{3 . 6}$ & PC1 & $\mathbf{2 7 . 5}$ \\
Chub Lake & $\mathbf{2 8 . 9}$ & $\mathbf{2 2 . 2}$ & CB1 & $\mathbf{2 8 . 2}$ \\
Harp Lake & $59.6^{*}$ & 43.0 & HP3A & $\mathbf{3 2 . 2}$ \\
& & HP4 & 55.0 \\
& & HP6 & $\mathbf{1 7 . 7}$ \\
* calculated using mean $1980-1985$ Na concentration; prior to road salt contamination. & \\
\hline
\end{tabular}




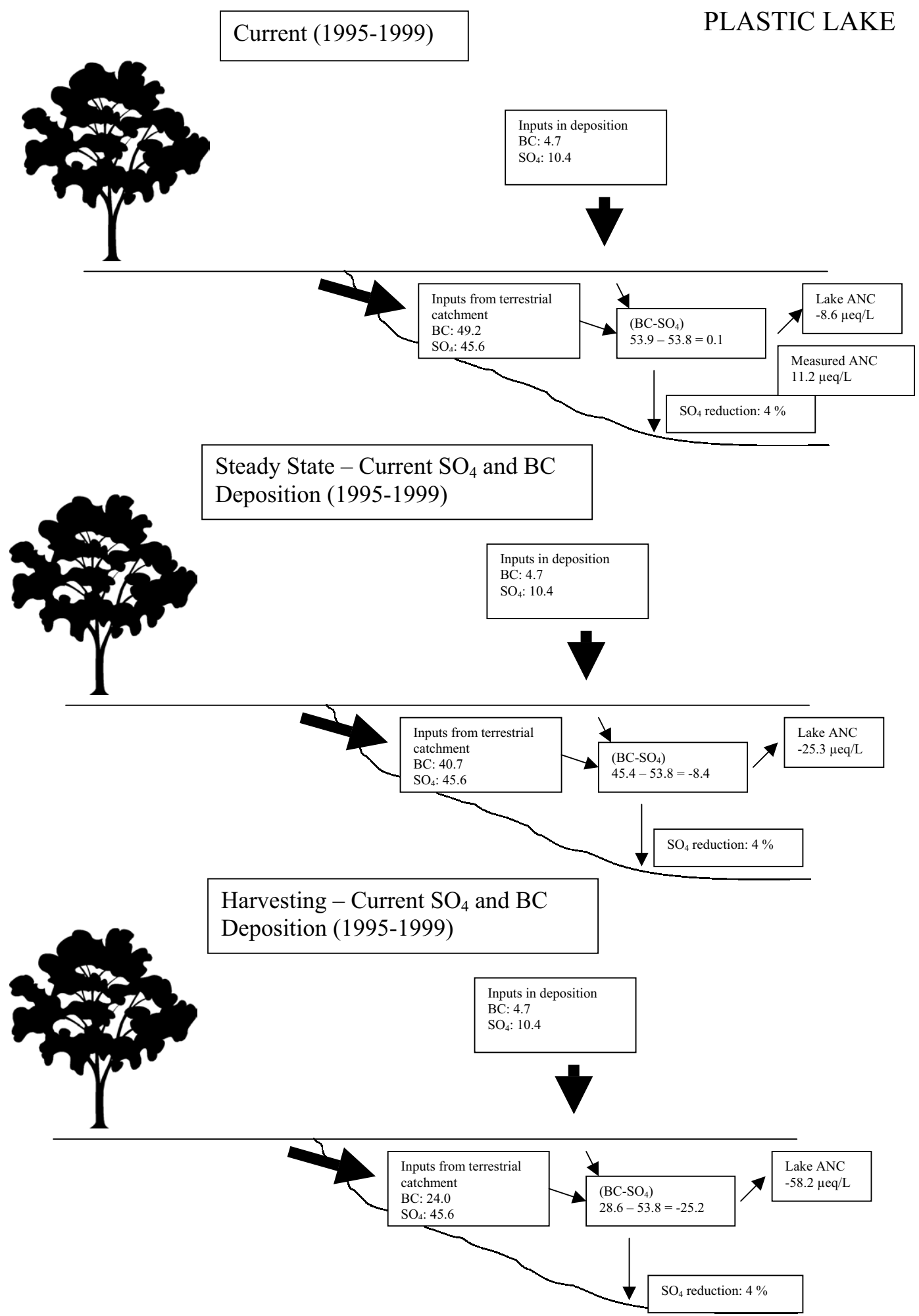

Fig. 1. The potential impact of harvesting on the ANC of Plastic Lake. Lake ANC $(2[\mathrm{Ca}]+2[\mathrm{Mg}]+[\mathrm{K}]+[\mathrm{Na}])-\left(2\left[\mathrm{SO}_{4}\right]-\left[\mathrm{NO} \mathrm{O}_{3}\right]-[\mathrm{Cl}]\right)$ was calculated under current (1995-1999) conditions (top), at steady state (no soil acidification), but assuming no change in deposition (middle) and under conditions that assume stem-only harvesting but no change in deposition (bottom). Base cation and sulphate inputs to the lake were calculated by weighting inputs from deposition and the terrestrial catchments relative to area of the lake and catchment respectively. Base cation inputs from the terrestrial catchment were obtained by including weathering estimates calculated by the Zr-depletion method. Measured ANC of the lake was obtained using the 1995-1999 average lake concentrations and an annual runoff of 0.52 m. In-lake retention was assumed to be 4\%. All fluxes are in meq $m^{-2} y^{-1}$ except lake ANC (measured and predicted) concentrations which are in $\mu e q / l$. 

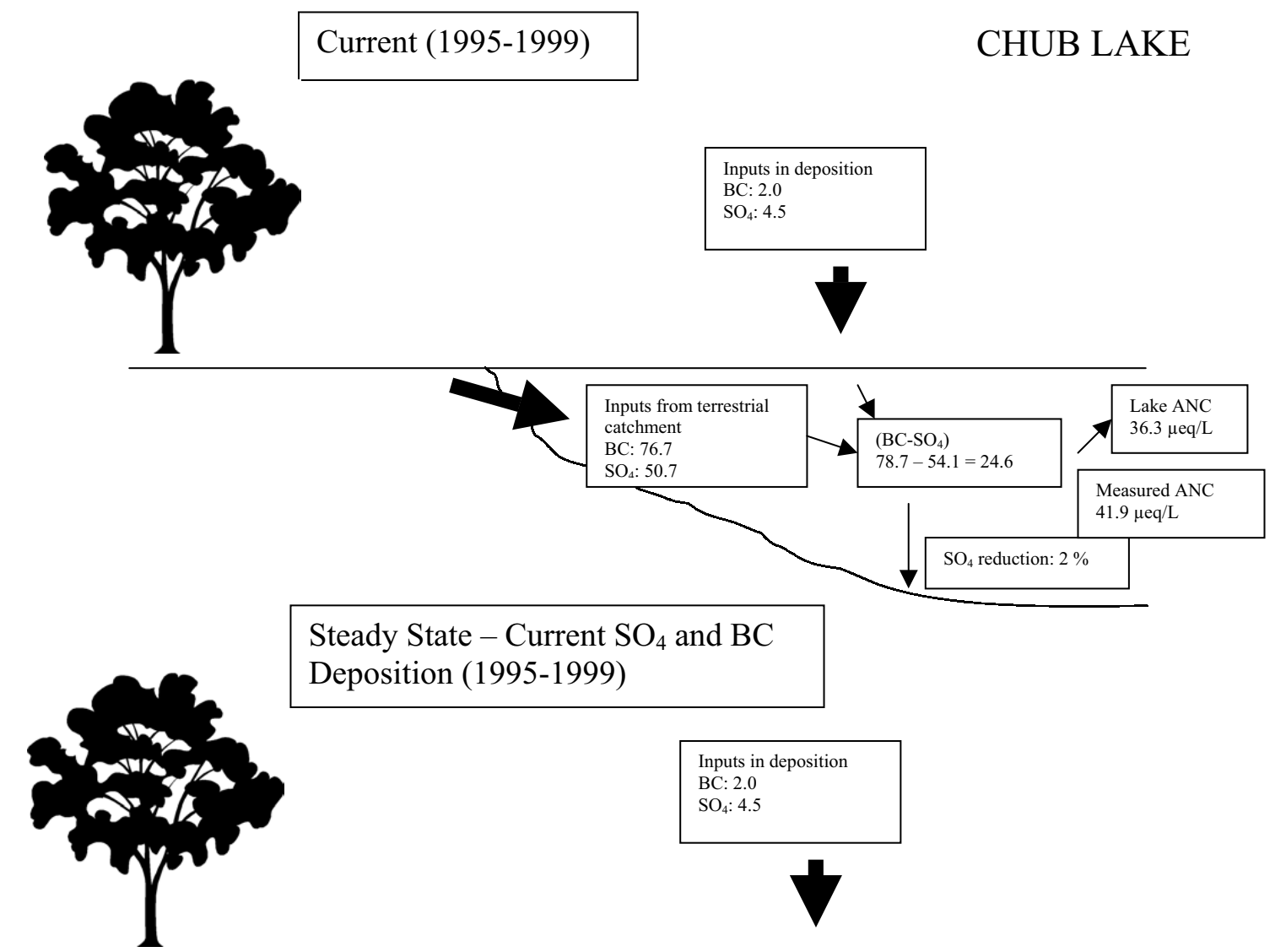

Inputs in deposition

BC: 2.0

$\mathrm{SO}_{4}: 4.5$

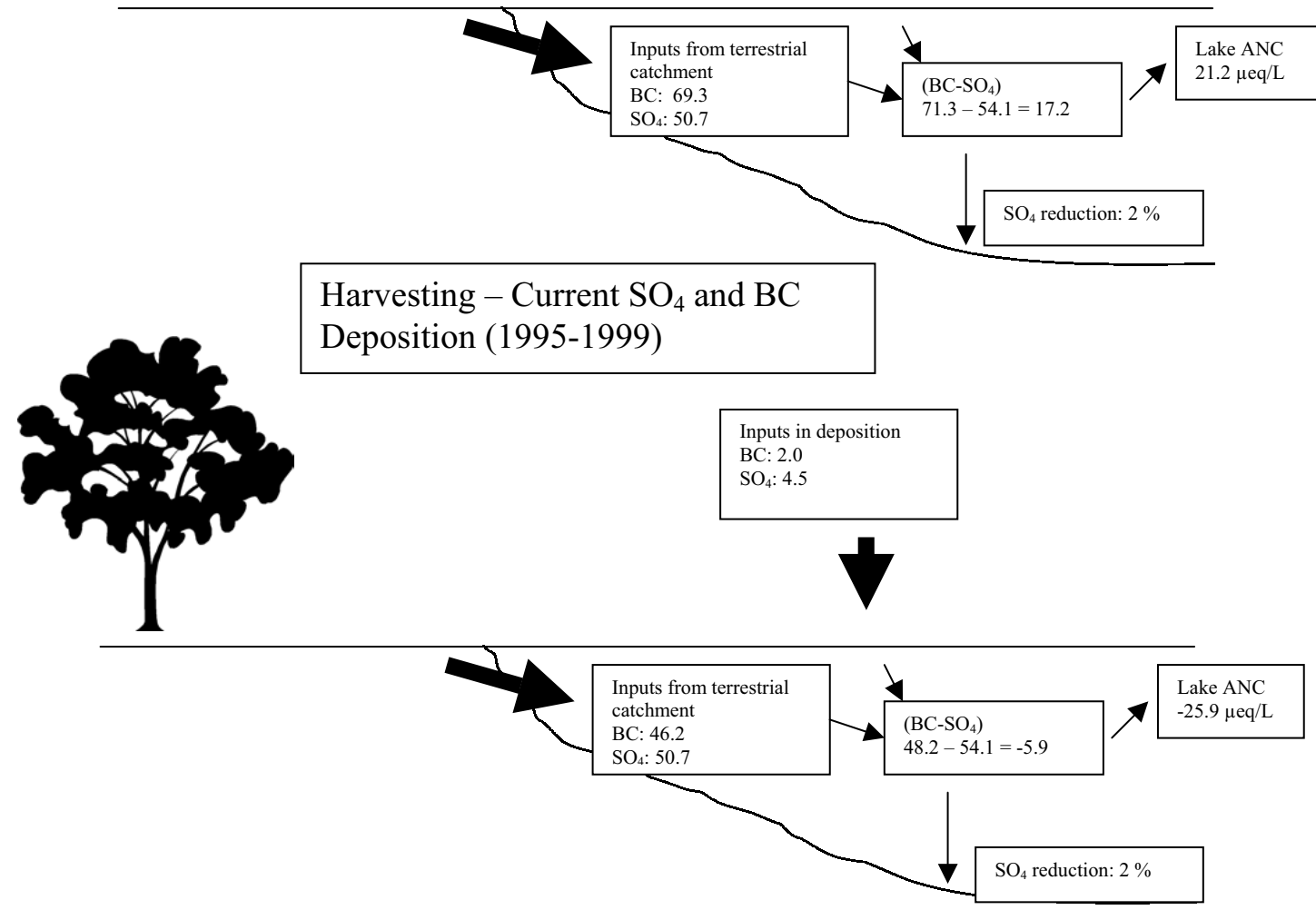

Fig. 2. The potential impact of harvesting on the ANC of Chub Lake. See Fig. 1 legend for further details. In-lake retention was assumed to be $2 \%$ and annual runoff was $0.49 \mathrm{~m}$. 


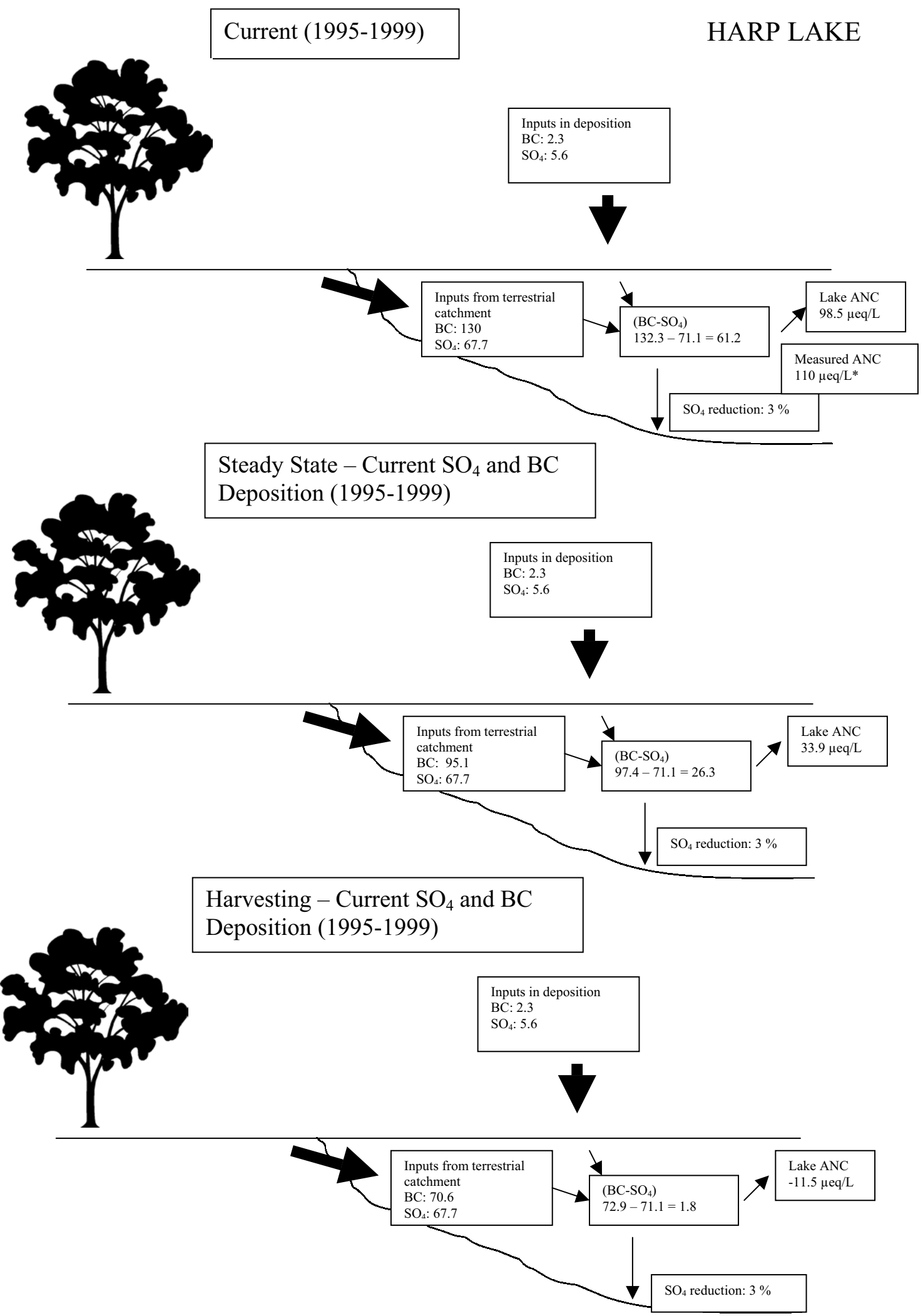

Fig. 3. The potential impact of harvesting on the ANC of Harp Lake. See Fig. 1 legend for further details. In-lake retention was assumed to be $3 \%$ and annual runoff was $0.54 \mathrm{~m}$. Measured ANC was calculated as stated in Fig. 1 except that average Na and Cl concentrations measured in 1980-1985 were used to calculate current ANC due to recent road salt contamination. 
Lake or at a similar catchment in this region, $\mathrm{BC}$ removals due to harvest should be included in the SSWC calculations and a much lower CL (A) for these lakes would be obtained (see Fig. 1).

In contrast, the forest at Harp Lake is typical of healthy actively-growing mixed hardwood forests in this region and net annual BC uptake by the forest (HP4) over this period was $\sim 37 \mathrm{meq} \mathrm{m}^{-2} \mathrm{yr}^{-1}$ (Watmough and Dillon, 2002). The estimated area-weighted annual BC uptake for the entire catchment that could potentially be removed during stemonly harvest was $\sim 25 \mathrm{meq} \mathrm{m}^{-2} \mathrm{yr}^{-1}$ (Fig. 3). In this case, the SSWC model should include an estimate of BC uptake when determining the pre-industrial $\mathrm{BC}$ input $\left(\mathrm{BC}_{\mathrm{o}}\right)$. However, the critical load obtained by the traditional SSWC model (84.1 meq $\mathrm{m}^{-2} \mathrm{yr}^{-1}$ ) (Table 3) is almost double the critical load obtained from soil measurements when harvesting is considered (43.0 meq $\mathrm{m}^{-2} \mathrm{yr}^{-1}$ ) (Table 4). This suggests that either the Zr-depletion method greatly under-estimates base cation weathering rates at Harp Lake or that the SSWC does not take harvest removals into account adequately. To assess these possibilities, the $\mathrm{BC}_{\mathrm{o}}$ input to Harp Lake was calculated assuming no net tree uptake (no harvesting) by subtracting current $\mathrm{BC}$ uptake rates. In this example an annual runoff of $\sim 0.5 \mathrm{~m}$ is assumed and the CL (Ac) (Eqn. 1) is $94.6 \mathrm{meq}$ $\mathrm{m}^{-2} \mathrm{yr}^{-1}\left(\mathrm{ANC}_{\text {limit }}\right.$ of $40 \mu$ eq $\mathrm{l}^{-1}$ ) (removes $\mathrm{N}_{\text {leach }}$ and $\mathrm{Cl}$ from the $\mathrm{CL}$ calculation). By rearranging Eqn. (1):

$$
\begin{aligned}
\mathrm{BC}_{\mathrm{w}}+\mathrm{BC}_{\mathrm{dep}} & =114.6 \mathrm{meq} \mathrm{m}^{-2} \mathrm{yr}^{-1}+25 \mathrm{meq} \mathrm{m}^{-2} \mathrm{yr}^{-1} \\
& =139.6 \text { meq } \mathrm{m}^{-2} \mathrm{yr}^{-1}
\end{aligned}
$$

Therefore, at steady state, if there were no net BC uptake (no harvesting), according to the SSWC calculation, the BC concentration in the lake should be approximately $280 \mu \mathrm{eq}^{-1}$ and the $\mathrm{BC}$ weathering rate in forest soils surrounding Harp Lake around $122 \mathrm{meq} \mathrm{m}^{-2} \mathrm{yr}^{-1}$. This compares to $\mathrm{BC}$ weathering estimates between 70.7 and $128.5 \mathrm{meq} \mathrm{m}^{-2} \mathrm{yr}^{-1}$ obtained from soil measurements at four sub-catchments surrounding Harp Lake (Table 2). Although these two estimates are reasonably close, it is very important to determine which approach is providing a better indicator of $\mathrm{BC}$ inputs into Harp Lake. Using $\mathrm{Ca}$ as an example, at least $70 \%$ of the Ca that enters Harp Lake is leached from the upper $(0-66 \mathrm{~cm})$ soil horizon (Watmough and Dillon $2002 \mathrm{~b}$ ). This weathering input of $\mathrm{Ca}$ from upper soil horizons at Harp Lake indicated by the SSWC model is far greater than that obtained by $\mathrm{Zr}$-depletion, which in turn is greater than those obtained using PROFILE (Watmough and Dillon 2002b). Both the Zr-depletion method and PROFILE over-estimated $\mathrm{Na}$ export from the forested catchments at Harp Lake demonstrating that, at least for $\mathrm{Na}$, these methods do not under-estimate the weathering rate.
Furthermore, in the early 1980 s, the BC concentration in Harp Lake was only $\sim 280 \mu$ eq $\mathrm{I}^{-1}$, and $\mathrm{Ca}+\mathrm{Mg}$ combined have declined by $\sim 20 \mu$ eq $1^{-1}$ since this period (Figure 4 ). If the SSWC predicts $\mathrm{BC}$ weathering rates accurately, the $\mathrm{BC}$ concentration should increase to around $280 \mu \mathrm{eq} 1^{-1}$ at steady state if harvesting does not occur and there is no net forest growth. Yet forest soils at Harp Lake still appear to be experiencing considerable net losses of $\mathrm{Ca}$ and $\mathrm{Mg}$ that are not due to tree growth alone (Watmough and Dillon, 2002). Because of lake residence time, it will take years before current $\mathrm{BC}$ concentrations in the lake reflect current $\mathrm{BC}$ inputs and it is more likely that $\mathrm{BC}$ concentrations in the lake will continue to fall, even if there is no further net forest growth. This implies that the SSWC does not take base cation removal sufficiently into account when calculating CLs for lakes surrounded by catchments that are harvested. Critical load estimates using the SSWC model appear to be more appropriate to forests that are not harvested. Therefore, harvesting removals should be considered separately when calculating critical loads for lakes in this region to ensure that lakes are protected from acid deposition (Table 4). Equation 3 should therefore be modified to account for harvest removals in this region:

$$
\mathrm{CL}(\mathrm{A})=\mathrm{CL}(\mathrm{Ac})-\mathrm{N}_{\text {leach }}-\mathrm{Cl}_{\text {dep }}-\mathrm{BC}_{\mathrm{u}}
$$

where $\mathrm{BC}_{\mathrm{u}}$ represents base cation removals during harvest (meq $\mathrm{m}^{-2} \mathrm{yr}^{-1}$ ).

COMPARING CRITICAL LOADS OF ACIDITY FOR LAKES AND THEIR SUB-CATCHMENTS USING BC ESTIMATES FROM SOIL MEASUREMENTS - NO HARVESTING

By using $\mathrm{BC}$ weathering estimates for the rooting zone $(0-50 \mathrm{~cm})$ and the entire soil profile based on soil measurements, the CL (A) for catchments and their lakes can be compared directly. If forests are not harvested $\left(\mathrm{BC}_{\mathrm{u}}\right.$ values not included), the CL (A) for forests at Plastic and Chub Lakes are higher than their respective lakes and the CL (A) is exceeded only at Plastic Lake (Table 3). In contrast, CLs (A) for forests at three of the four subcatchments at Harp Lake are lower than the CL (A) for the lake. The lowest CLs (A) occurs at HP3A and HP6 where $\mathrm{NO}_{3}$ leaching losses are the greatest (Table 2). These high $\mathrm{NO}_{3}$ leaching losses, however, appear due to the physical, hydrological and biological characteristics of these subcatchments rather than $\mathrm{N}$ deposition (Devito et al., 1999; Watmough and Dillon, 2002). Nevertheless, CLs (A) are not exceeded at any of the forest catchments considered in this study if the forests are not harvested (Table 3 ). 

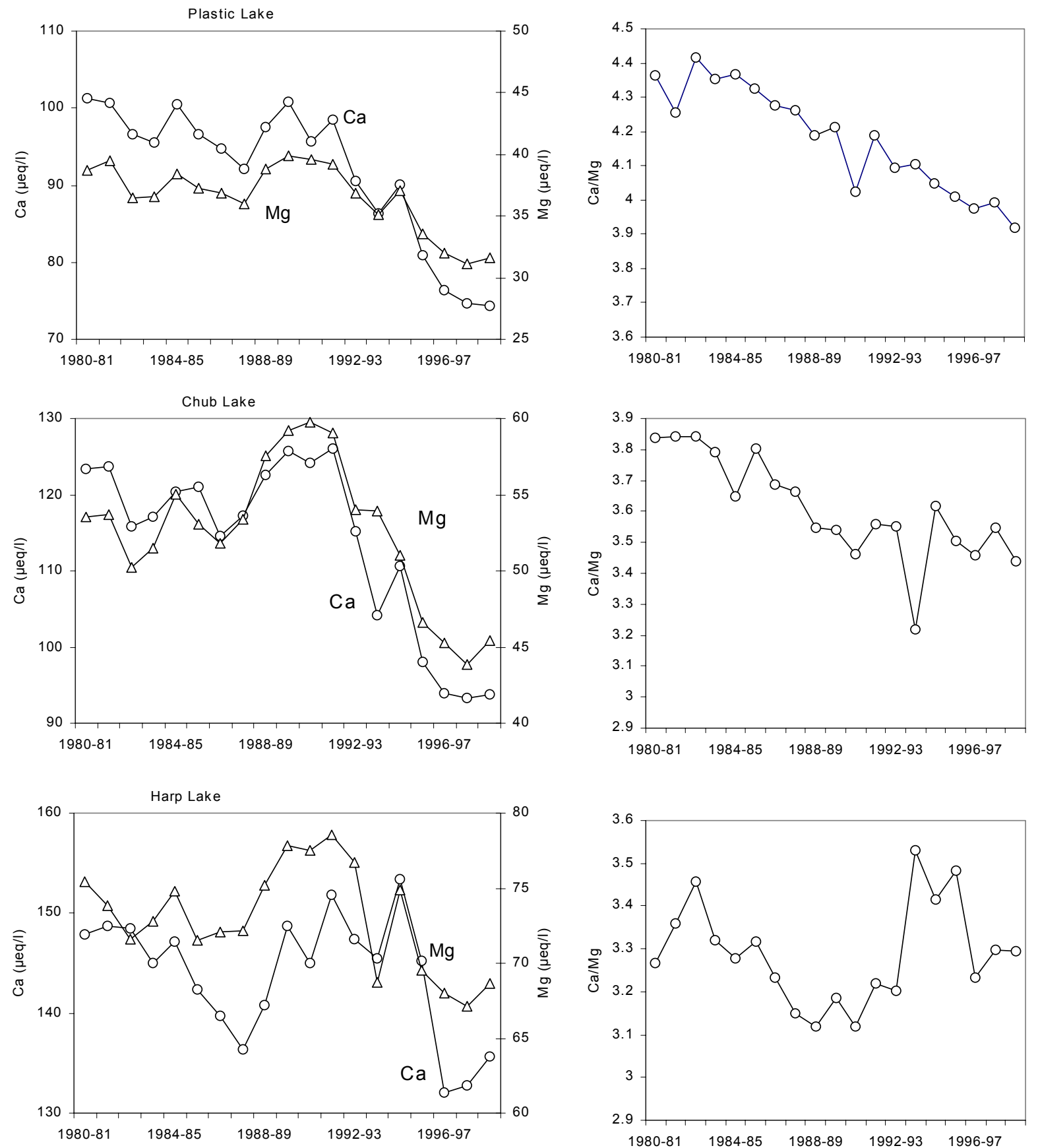

Fig. 4. Change in mean annual [Ca] and [Mg] concentrations and [Ca]/[Mg] ratio at Plastic (top), Chub (middle) and Harp (bottom) lakes between 1980/81 and 1998/99.

\section{COMPARING CRITICAL LOADS FOR ACIDITY FOR} LAKES AND THEIR SUB-CATCHMENTS USING BC ESTIMATES FROM SOIL MEASUREMENTS - WITH

\section{HARVESTING}

Inclusion of a harvest removal in the critical load calculations greatly increases the sensitivity of forests and lakes to acid deposition (Table 4; Figs. 1-3). However, BC removals due to selective harvesting in this region are quantified poorly. In this study, $\mathrm{BC}$ removal rates were calculated by determining the present $\mathrm{BC}$ content of stems ( $>10 \mathrm{~cm}$ except for Plastic Lake where $>12 \mathrm{~cm}$ was used) in the six sub-catchments divided by 80 - an assumed average rotation length. While this method is unlikely to estimate $\mathrm{BC}$ removals from the entire forested catchments accurately, it does allow the assessment of the potential impact of harvesting on critical loads for forests and lakes. Critical loads can be refined once better data on nutrient removals 
during harvest are available, although harvesting removals are not excessive; annual Ca removal rates used in this study are approximately equal to harvesting a single $45-\mathrm{cm}$ (d.b.h.) sugar maple tree per hectare per year.

Critical loads of acidity at Plastic and Chub Lake are lower than their respective forests, although CL (A) for both forests and lakes are currently exceeded if harvesting occurs (Table 4). In contrast, CLs (A) at three of the four sub-catchments at Harp Lake are lower than the CL (A) for the lake (three are currently exceeded), primarily because $\mathrm{NO}_{3}$ leaching losses from HP3A and HP6 are relatively high.

However, harvesting clearly has an enormous impact on the sensitivity of lakes and forests to acid deposition. Helliwell et al. (2001) have shown that afforestation can have a deleterious effect on surface water chemistry. Dynamic model predictions obtained using MAGIC also generally indicate that chemical improvement of surface waters will not be as pronounced at afforested sites compared with non-forested sites in the UK (Evans and Monteith, 2001). Based on model predictions for an upland site in Scotland, Jenkins et al. (1990) reported that "in sensitive areas, replanting of a felled forest without treatment of the soil by addition of base cations, should not be undertaken even if significant deposition reductions are realized". The impact of harvesting on stream chemistry has been well documented, with increases in $\mathrm{K}$ and $\mathrm{NO}_{3}$ in streams being particularly evident in the years immediately following harvest (Reynolds et al., 1995). In all steady state critical load calculations, however, a long-term approach is taken and it is assumed that trees can access $\mathrm{BC}$ only from the exchangeable pool and that the only net inputs of $\mathrm{BC}$ to this pool are mineral weathering and atmospheric deposition. If trees can access $B C$ from sources other than the exchangeable pool (Blum et al., 2002), or if net inputs of $\mathrm{BC}$ change after harvesting (i.e. increased mineral weathering), then these calculations on the long-term impact of harvesting on stream water and soil chemistry will need to be revised. Conversely it may be argued that enhanced leaching losses of $\mathrm{BC}$ in stream water immediately following harvest should be taken into account and included as a harvest removal. The impact of harvesting on $\mathrm{BC}$ budgets clearly requires further investigation so that critical load models may be improved; effective calculation of CL (A) for lakes and forests for the region necessitates that $\mathrm{BC}$ removals due to harvesting throughout the area are assessed more precisely. As almost $70 \%$ of $~ 1500$ lakes assessed in this region were more sensitive to acid deposition than Harp Lake (Henriksen et al., 2002), the potential negative impact of harvesting in south-central Ontario could be substantial.
ARE FORESTS BEING OVER-PROTECTED BY

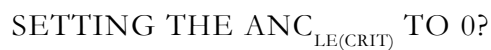

In Europe, critical loads for forests are usually calculated using a BC:Al or $\mathrm{Ca}: \mathrm{Al}$ ratio of 1.0 (Posch et al., 1995); if applied in this study, such chemical criteria would increase the $\mathrm{CL}$ for forests considerably. Calculating an acceptable $\mathrm{ANC}_{\text {le(rrit) }}$ for forest soils has been greatly debated in recent years (Gorannsson and Eldhuset, 2002; Lokke et al., 1996) and in this study a very conservative approach was used by setting the $\mathrm{ANC}_{\text {le(rit) }}$ to 0 . However, the most acid-sensitive lakes such as Plastic and Chub Lakes that are surrounded by shallow soils are more sensitive to acid deposition than forests, even using an $\mathrm{ANC}_{\text {le(rit) }}$ of 0 . Hence acceptable $\mathrm{S}$ deposition levels should be limited by the sensitivity of the most acid-sensitive lakes in this region. However, if harvesting in this region is confined to catchments with relatively deep soils (i.e. Harp Lake), where lakes are relatively insensitive to acid deposition, a situation may arise whereby CLs will be determined by the sensitivity of these forests. Although this situation is unlikely and some harvesting will probably occur in more acid-sensitive catchments, it demonstrates the tremendous impact of harvesting on CL calculations and highlights the need for more reliable estimates of harvest removals in the region.

\section{OTHER CONSIDERATIONS}

Critical load exceedances in this study are calculated using only bulk deposition measurements and this method does not account for some dry deposition. Currently, $\mathrm{SO}_{4}$ export from the six sub-catchments exceeds input in bulk deposition by between $\sim 40-100 \%$, although the source(s) of all this excess $\mathrm{SO}_{4}$ are unknown. If it is solely an external source (dry deposition) or a permanent internal source (weathering), it should be included in the critical load calculations. However, some of the net $\mathrm{S}$ release is likely to be from temporary internal sources such as desorption, mineralisation or net release from wetlands associated with climate events (Eimers and Dillon, 2002; Devito et al., 1999; Dillon et al., 1997; Mitchell et al., 2001). In this instance, in the strict sense of the CL, the excess S should not be included in the calculation because it will not exist at steady state. Presently, the relative contribution from these temporary internal sources are unknown, but there has been no change in the percentage of net $\mathrm{SO}_{4}$ export from the six sub-catchments over the past 20 years. Current base cation pools in soils in this region are low and therefore unless $\mathrm{SO}_{4}$ export reaches equilibrium with $\mathrm{SO}_{4}$ inputs soon, $\mathrm{SO}_{4}$ leaching may exceed the CLs for soils and lakes indefinitely. Calculations, using $\mathrm{BC}_{\mathrm{o}}$ estimates from soil measurements, 
suggest that current $\mathrm{SO}_{4}$ inputs into the lakes must be reduced by between 0 and $56 \%$ if harvesting does not occur, and by between 37 and $92 \%$ if harvesting occurs to maintain the ANC of the three lakes above $40 \mu \mathrm{eq} \mathrm{l}^{-1}$ (Table 5). Similarly, $\mathrm{SO}_{4}$ leaching from soils must be reduced by between 0 and $46 \%$ (no harvesting) or by between 16 and $79 \%$ (harvesting) to keep above $0 \mu$ eq $1^{-1}$ the ANC in water draining the rooting zone of all six sub-catchments. These calculations for lakes do not include in-lake $\mathrm{S}$ retention processes (included in Figs. 1-3) which, for simplicity, have been excluded in these calculations. If in-lake $\mathrm{S}$ retention values $(2-4 \%)$ were included in this study, CLs (A) for lakes would increase slightly.

\section{THE ROLE OF NITROGEN IN THE ACIDIFICATION}

\section{OF LAKES AND SOILS}

In this study, a very simplistic approach to the role of $\mathrm{N}$ in the acidification of lakes and soils was taken. It was assumed that $\mathrm{NO}_{3}$ leaching from soils and, therefore, concentrations in lakes, are determined by lake and catchment characteristics rather than by the level of $\mathrm{N}$ deposition and that $\mathrm{NO}_{3}$ leaching from catchments will not increase under current deposition levels. Similarly, it is assumed that current $\mathrm{NO}_{3}$ leaching from some of the catchments will not decrease if $\mathrm{N}$ deposition decreases. These assumptions obviously need further investigation. The SMB model for $\mathrm{S}+\mathrm{N}$ and the FAB model include $\mathrm{N}$ dynamics in soils and lakes, but input values used in these models, particularly $\mathrm{N}$ behaviour in soils, are poorly characterised. The simple approach used in this study can be easily justified in areas where harvesting occurs; under these conditions net $\mathrm{N}$ accumulation in soil is low (Watmough and Dillon, 2002) and increased $\mathrm{NO}_{3}$ leaching due to $\mathrm{N}$ saturation is extremely unlikely. In contrast, in areas that are not harvested, current $\mathrm{N}$ accumulation in soil $\left(\sim 45 \mathrm{meq}^{-2} \mathrm{yr}^{-1}\right)$ may ultimately result in increased $\mathrm{NO}_{3}$ leaching. However, lakes surrounded by forests that are not harvested have much higher CLs (A) than harvested areas and, even if $\mathrm{NO}_{3}$ leaching were to increase, harvested catchments are still more sensitive to acid deposition. Of course, this may not protect lakes and forests from biological effects related to excessive $\mathrm{N}$ accumulation such as nutrient imbalances in trees, changes in species composition and eutrophication of lakes (Aber $e t$ al., 1989). As forests in many parts of the region are harvested and, therefore, require substantial amounts of $\mathrm{N}$, the safest approach is to set $\mathrm{N}$ deposition levels that meet the demands of these forests plus some immobilization in soils. For this region, a target deposition of $\sim 40-50 \mathrm{meq}$ $\mathrm{m}^{-2} \mathrm{yr}^{-1}$ is reasonable compared with current deposition levels around $60 \mathrm{meq} \mathrm{m}^{-2} \mathrm{yr}^{-1}$.

\section{CALCIUM LIMITATION}

All current calculations are based on setting a critical chemical criterion that is based on the difference between strong anions and strong cations (ANC) in soil water or in the lake. Therefore, particularly in areas that are harvested, it is assumed that low $\mathrm{Ca}$ (and $\mathrm{Mg}$ ) levels in water draining the rooting zone and in lakes can occur without harmful effects on biota. For example, CL calculations for the forests suggest that if stem-only harvesting continues, at steady state, $\mathrm{Ca}$ levels in water draining the rooting zone of forests will be between $9 \mu$ eq $1^{-1}$ and $27 \mu$ eq $\mathrm{l}^{-1}$. If these low concentrations can be maintained without affecting forest productivity (Adams, 1999; Adams et al., 2000), Ca levels in lakes will be substantially lower at steady state (Fig. 4). Presently, Ca concentrations in lakes are between $79 \mu \mathrm{eq}$ $1^{-1}$ (Plastic Lake) and $140 \mu$ eq $1^{-1}$ (Harp Lake), but have been decreasing over the past 20 years due to a decrease in $\mathrm{Ca}$ leaching from the surrounding catchments (Fig. 4). This decrease in $\mathrm{Ca}$ and $\mathrm{Mg}$ concentration, however, is not monotonic; concentrations are greatly influenced by changes in $\mathrm{SO}_{4}$ concentration in the lake, which appear to be a result of climate-induced increases in leaching losses from catchments (Fig. 5; Eimers and Dillon, 2002). Furthermore, Ca losses from the exchangeable soil pools at Plastic and Chub Lake have exceeded Mg losses, resulting in a decrease in the $\mathrm{Ca}: \mathrm{Mg}$ ratio in stream and lake water (Fig. 4). In contrast, at Harp Lake, the relative Mg losses from some of the catchments are comparable to $\mathrm{Ca}$; there has been no decrease in the $\mathrm{Ca}: \mathrm{Mg}$ ratio in these streams or in the lake over the study period (Watmough and Dillon, 2002).

Decreases in $\mathrm{Ca}$ (and $\mathrm{Mg}$ ) levels in lakes are commonly associated with decreases in $\mathrm{SO}_{4}$ levels (Evans and Monteith, 2001; Moldan et al., 2001), and concern has been expressed

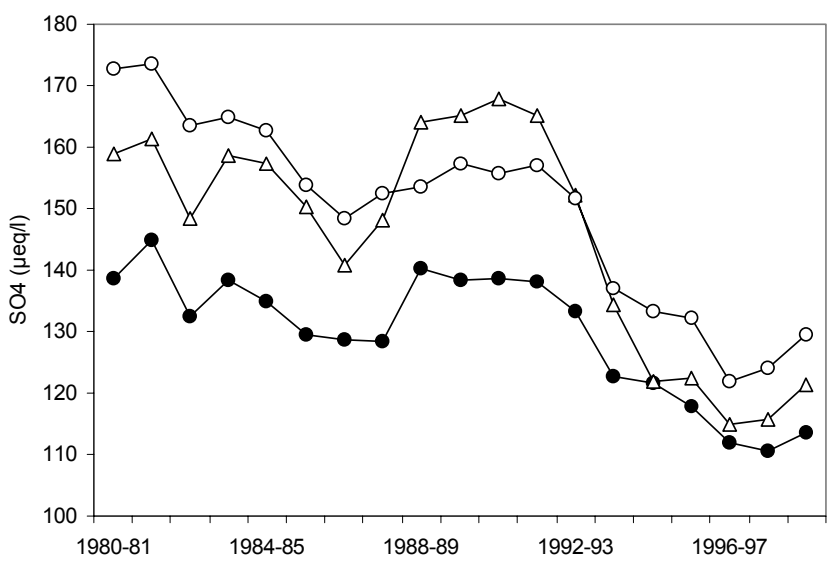

Fig. 5. Change in mean annual $\left[\mathrm{SO}_{4}\right]$ concentrations in Plastic, Chub and Harp lakes between 1980/81 and 1998/99. 
Table 5. The percentage reduction in current $\mathrm{SO}_{4}$ inputs into lakes and $\mathrm{SO}_{4}$ leaching from catchments required to prevent excessive acidification of soils ( $\mathrm{ANC}=0 \mu \mathrm{eq} \mathrm{l}^{-1}$ ) or to maintain the lake ANC above $40 \mu \mathrm{eq}{ }^{1-1}$.

\begin{tabular}{lcclcl}
\hline & No Harvesting & Harvesting & Catchment & No Harvesting & Harvesting \\
\hline Plastic Lake & $55.5 \%$ & $92.1 \%$ & PC1 & $18.4 \%$ & $54.9 \%$ \\
Chub Lake & $10.6 \%$ & $56.2 \%$ & CB1 & $4.6 \%$ & $50.5 \%$ \\
Harp Lake & $0 \%$ & $36.5 \%$ & HP3A & $20.1 \%$ & $57.6 \%$ \\
& & & HP4 & $0 \%$ & $16.0 \%$ \\
& & & HP6 & $46.4 \%$ & $79.0 \%$ \\
& & & HP6A & $3.9 \%$ & $43.1 \%$
\end{tabular}

The calculations assume that $\mathrm{NO}_{3}$ export from catchments and $\mathrm{NO}_{3}$ levels in lakes will not change in response to deposition or management practices. $\mathrm{BC}$ inputs for these calculations are obtained from soil measurements (Zr-depletion method) in the rooting zone (catchments) and for the entire soil profile (lakes).

that decreasing $\mathrm{BC}$ levels may be delaying biological recovery (Skeffington and Brown, 1992). In fact, low Ca concentrations alone may have strong negative effects on lake biota (Alstad et al., 1999; Hessen et al., 2000; Lien et al., 1996: Tessier and Horwitz, 1990). It is, therefore, important to understand the cause of the $\mathrm{BC}$ decrease and to consider how to achieve the predicted concentrations of $\mathrm{BC}$ in lakes. Similar large decreases in Ca concentrations in lakes in north-western Ontario have also been reported in recent decades (Keller et al., 2001); they attributed this decrease in lake $\mathrm{Ca}$ levels to a decrease in $\mathrm{Ca}$ weathering and suggested that present $\mathrm{Ca}$ levels are far below those that existed in pre-industrial times. If this were the case, and $\mathrm{Ca}$ weathering rates (but apparently not those for other base cations) decreased rapidly in recent decades, all steady state critical loads models are invalid because they assume base cation weathering rates do not change appreciably over the time-scale considered. Furthermore, for lake $\mathrm{Ca}$ concentrations to decrease from the onset of industrialisation implies that forest soils have not acidified; otherwise, there would have been a substantial increase in Ca leaching and lake $\mathrm{Ca}$ levels during soil acidification. The only way to explain a consistent decrease in lake Ca levels and soil acidification is if $\mathrm{Ca}$ weathering rates decreased dramatically at the onset of industrialisation at all the lake catchments, at approximately the same time, which seems implausible.

Results of this study suggest that $\mathrm{Ca}$ (and $\mathrm{Mg}$ ) levels in lakes are decreasing and will continue to do so until steady state is reached (no soil acidification). In contrast to the suggestions by other workers (Keller et al., 2001; Clair et al., 2002), the decrease in $\mathrm{Ca}$ and $\mathrm{Mg}$ is unlikely to be due to a decrease in mineral weathering. In this region, plagioclase feldspar weathering (releases $\mathrm{Ca}$ and $\mathrm{Na}$ ) is responsible for 'acid-buffering' in soils (Kirkwood, 1990) and $\mathrm{Na}$ concentrations in lakes that are unaffected by road salt have not changed over time (Fig. 6). As a result, even without harvesting, Ca concentrations in lakes may decrease to between $\sim 40 \mu$ eq $1^{-1}$ (Plastic Lake) and $\sim 90 \mu$ eq $1^{-1}$ (Harp Lake), and will be close to pre-industrial levels, assuming that soils were close to steady sate prior to human disturbance. However, under conditions of stem-only harvesting or if there is considerable net retention of $\mathrm{Ca}$ in forest soils (increase in soil base saturation), Ca levels will fall to values far below those that existed in pre-industrial times. If harvesting occurs, it is calculated that $\mathrm{Ca}$ concentrations in the three lakes at steady state would be between $\sim 25$ and $\sim 52 \mu$ eq $1^{-1}$ - approximately $30 \%$ of current $\mathrm{Ca}$ concentrations (Fig. 7). Therefore, even if $\mathrm{S}$ inputs meet the CL, if forests are harvested, lakes will be more dilute, the contribution of $\mathrm{Na}$ to the total base cation concentration in lakes will be much larger and many lakes will be more acidic (many lakes currently have an ANC above $40 \mu \mathrm{eq}^{-1}$ ). Therefore, a critical ANC level of $40 \mu \mathrm{eq}$ $1^{-1}$ may not be the most appropriate criterion for predicting

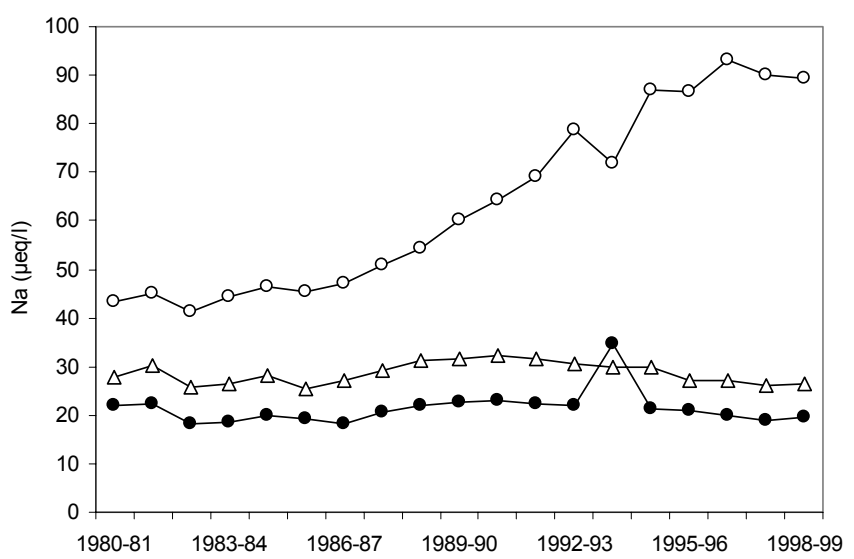

Fig. 6. Change in mean annual [Na] concentrations in Plastic, Chub and Harp lakes between 1980/81 and 1998/99. 
future biological effects in lakes.

\section{Conclusions}
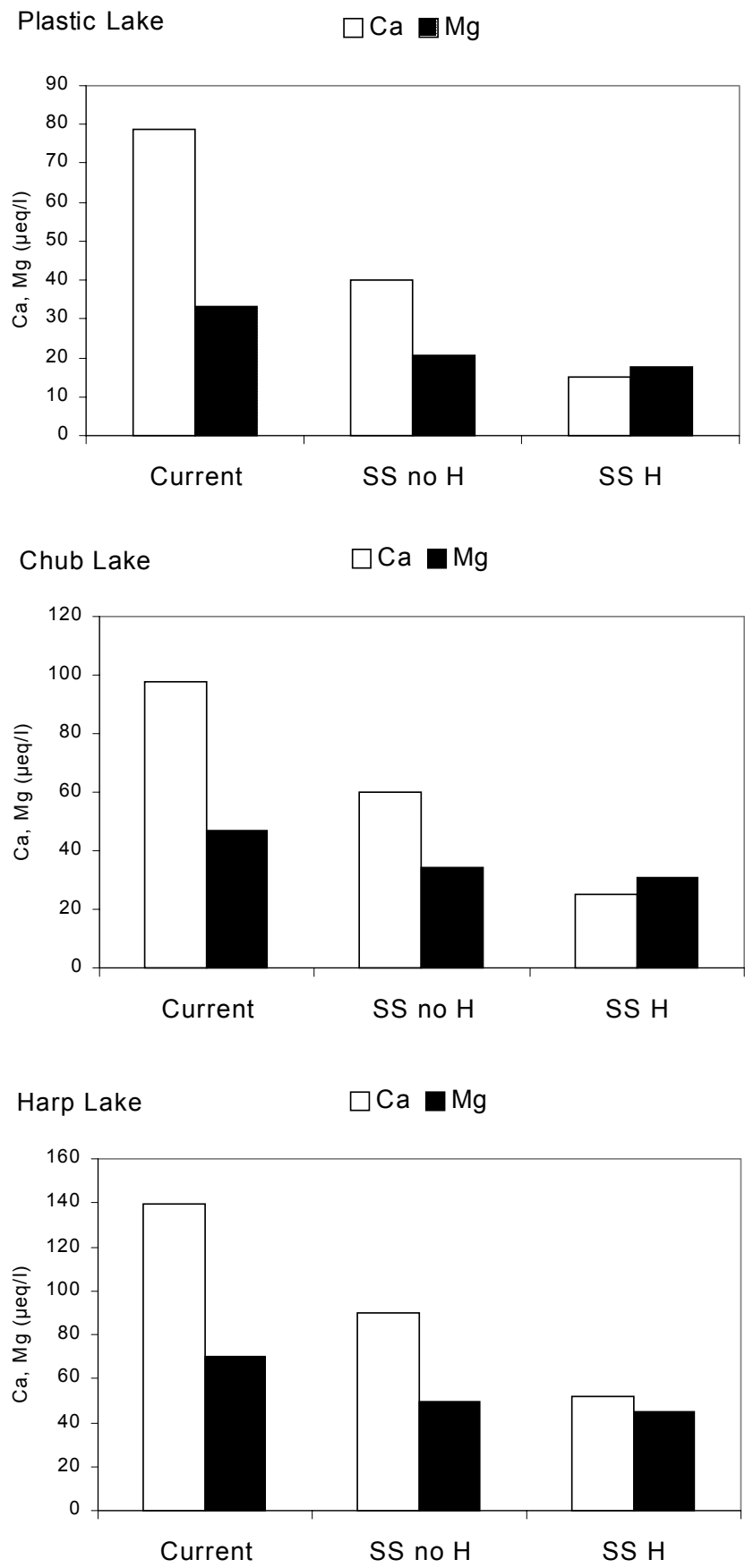

Fig. 7. Predicted concentrations of [Ca] and [Mg] in Plastic (top), Chub (middle) and Harp (bottom) lakes under current (1995-1999) conditions, at steady state (no soil acidification), but assuming no change in deposition and under conditions that assume stem-only harvesting but no change in deposition. Base cation inputs from the terrestrial catchment were obtained by including weathering estimates calculated by the Zr-depletion method.
Critical loads for acidity, calculated for three lakes and their representative forested sub-catchments in south central Ontario, were between 7 and $19 \mathrm{meq} \mathrm{m}^{-2} \mathrm{yr}^{-1}$ higher using the traditional SSWC model (F-factor) derived from soil measurements and CLs (A) than those for lakes and forests were much lower under conditions that assume harvesting. Critical loads for acidity at the most acid-sensitive lakes were much lower than CL (A) for their corresponding catchments. Therefore, setting acid deposition levels that protect the majority of lakes in the region should prevent the ANC in water draining the rooting zone of forest soils from falling below $0 \mu$ eq $\mathrm{I}^{-1}$, unless harvesting occurs only in the least acid-sensitive catchments. However, current $\mathrm{S}$ inputs into lakes greatly exceed inputs measured in bulk deposition and the source of this 'excess' $\mathrm{S}$ needs to be identified to calculate acceptable $\mathrm{S}$ deposition levels. Currently, if forests are undisturbed (no harvest), $\mathrm{S}$ inputs into the lakes must be reduced by between 0 and $56 \%$ to prevent the ANC in lakes from falling below the critical limit of $40 \mu \mathrm{eq} \mathrm{l}^{-1}$. Similarly, to prevent the ANC of water draining the rooting zone of soils from falling below $0 \mu \mathrm{eq}$ $1^{-1}$ at all six sub-catchments, $\mathrm{S}$ leaching must be reduced by up to $46 \%$. However, if harvesting occurs (or continues), $\mathrm{S}$ inputs to lakes must be reduced by between 37 and $92 \%$ and $\mathrm{S}$ leaching from soils must be reduced by between 16 and $79 \%$ to achieve the same goals. Calculations that take into account base cation harvest removals assume that extremely low $\mathrm{Ca}$ leaching losses from forest soils and low Ca levels in lakes can occur without any detrimental effects on biota: this requires urgent investigation.

\section{Acknowledgements}

This study was supported by grants from the National Science and Engineering Research Council of Canada (NSERC), Ontario Power Generation Inc. and by the Ontario Ministry of the Environment. Joe Findeis is thanked for assistance with data management.

\section{References}

Aber, J.D., Nadelhoffer, K.J., Steudler, P. and Melillo, J.M., 1989. Nitrogen saturation in northern forest ecosystems. Bioscience 39, 378-386.

Adams, M.B., 1999. Acidic deposition and sustainable forest management in the central Appalachians, USA. Forest Ecol. Manage. 122, 17-28.

Adams, M.B., Burger, J.A., Jenkins, A.B. and Zelazny, L., 2000. Impact of harvesting and atmospheric pollution on nutrient depletion of eastern US hardwood forests. Forest Ecol. Manage. 138, 301-319.

Alstad, N.W., Skardal, L. and Hessen, D.O., 1999. The effect of calcium concentration on the calcification of Daphnia magna. Limnol. Oceanogr. 44, 2011-2017. 
Arp, P.A., Oja, T. and Marsh, M., 1996. Calculating critical S and $\mathrm{N}$ loads and current exceedances for upland forests in southern Ontario, Canada. Can. J. Forest. Res. 26, 696-709.

Blum, J.D., Klaue, A., Nezat, C.A., Driscoll, C.T., Johnson, C.E., Siccama, T.G., Eager, C., Fahey, T.J. and Likens, G.E., 2002. Mycorrhizal weathering of apatite as an important calcium source in base-poor forest ecosystems. Nature 417, 729-731.

Brakke, D.F., Henriksen, A. and Norton, S.A., 1989. Estimated background concentrations of sulfate in dilute lakes. Water Resour. Bull., 25, 247-253.

Canadian Soil Survey Committee 1978. The Canadian system of soil classification. Canadian Department of Agriculture Publication 1646. Supply and Services Canada, Ottawa, Ontario.

Clair, T.C., Ehrman, J.M., Ouellet, A.J., Brun, G., Loackerbie, D. and Ro, C., 2002. Changes in freshwater acidification trends in Canada's Atlantic Provinces: 1983-1997. Water Air Soil Pollut., 135, 335-354.

Cronan, C.S. and Grigal, D.F., 1995. Use of calcium/aluminum ratios as indicators of stress in forest ecosystems. J. Environ. Qual. 24, 209-226.

Devito, K.J., Westbrook, C. and Schiff, S., 1999. Nitrogen mineralization and nitrification in upland and peatland forest soils in two Canadian Shield catchments. Can. J Forest. Res. 29, 1793-1804.

Dillon, P.J. and Molot, L.A., 1990. The role of ammonium and nitrate retention in the acidification of lakes and forested catchments. Biogeochemistry 11, 23-43.

Dillon, P.J., Molot, L.A. and Futter, M., 1997. The effect of El Nino-related drought on the recovery of acidified lakes. Environ. Monit. Assess., 46, 105-111.

Eimers, M.C. and Dillon, P.J., 2002. Climate effects on sulphate flux from forested catchments in south-central Ontario. Biogeochemistry 61, 337-355.

Evans, C.D. and Monteith, D.T., 2001. Chemical trends at lakes and streams in the UK Acid Waters Monitoring Network, 1988 -2000; Evidence for recent recovery at a national scale. Hydrol. Earth Syst. Sci., 5, 351-366.

Evans, C., Jenkins, A., Helliwell, R., Ferrier, R. and Collins, R., 2001. Freshwater Acidification and Recovery in the United Kingdom. Centre for Ecology and Hydrology, Maclean Building, Crowmarsh Gifford, Wallingford, ISBN No. 1-903741-01-7.

Gorannsson, A. and Eldhuset, T.D., 2001. Is the $\mathrm{Ca}+\mathrm{K}+\mathrm{Mg} / \mathrm{Al}$ ratio in the soil solution a predictive tool for estimating forest damage? Water Air Soil Pollut.: Focus 1, 57-74.

Hall, J., Reynolds, B., Aherne, J. and Hornung, M., 2001. The importance of selecting appropriate criteria for calculating acidity critical loads for terrestrial ecosystems using the simple mass balance equation. Water Air Soil Pollut.: Focus 1, 29-41.

Helliwell, R.C, Ferrier, R.C., Johnston, L., Goodwin, J. and Doughty, R., 2001. Land use influences on acidification and recovery of freshwaters in Galloway, south-west Scotland. Hydrol. Earth. Syst. Sci., 5, 451-458.

Henriksen, A. and Dillon, P.J., 2001. Critical Load of Acidity to Surface Waters in South-Central Ontario, Canada I. Application of the Steady-State Water Chemistry (SSWC) Model. Acid Rain Research Report 2001:52. Norwegian Institute for Water Research (NIVA), Oslo.

Henriksen, A. and Posch, M., 2001. Steady-state models for calculating critical loads of acidity for surface waters. Water Air Soil Pollut.: Focus 1, 375-398.

Henriksen, A., Dillon, P.J. and Aherne, J., 2002. Critical loads of acidity for surface waters in south-central Ontario, Canada: regional application of the steady-state water chemistry model. Can. J. Fish. Aquat. Sci., 59, 1287-1295.

Hessen, D.O., Faafeng, B.A. and Andersen, T., 1995. Replacement of herbivore zooplankton species along gradients of ecosystem productivity and fish predation pressure. Can. J. Fish. Aquat. Sci., 52, 733-742.

Hessen, D.O. and Rukke, N.A., 2000. UV radiation and low calcium as mutual stressors for Daphnia. Limnol. Oceanogr. 45, 1834-1837.

Hessen, D.O., Alstad, N.E.W. and Skardal, L., 2000. Calcium limitation in Daphnia magna. J. Plank. Res., 22, 553-568.

Houle, D. and Carignan, R., 1995. Role of $\mathrm{SO}_{4}$ adsorption and desorption in the long-term $\mathrm{S}$ budget of a coniferous catchment on the Canadian Shield. Biogeochemistry 28, 162-182.

Jenkins, A., Cosby, B.J., Ferrier, R.C., Walker, T.A.B. and Miller, J.D. 1990. Modelling stream acidification in afforested catchments: an assessment of the relative effects of acid deposition and afforestation. J. Hydrol., 120, 163-181.

Keller, W., Dixit, S.S. and Heneberry, J., 2001. Calcium declines in northeastern Ontario lakes. Can. J. Fish. Aquat. Sci., 58, 2011-2020.

Kirkwood, D.E., 1990. Weathering rates within the soils of Plastic lake. MSc. Thesis, University of Western Ontario, London, Ontario.

Lien, L., Raddum, G.G., Fjellheim, A. and Henriksen, A., 1996. A critical limit for acid neutralizing capacity in Norwegian surface waters, based on new analyses of fish and invertebrate responses. Sci. Total. Environ., 177, 173-193.

Lokke, H., Bak, J., Falken-Grerup, U., Finlay, R.D., Ilvesniemi, H., Nygaard, P.H. and Starr, M., 1996. Critical loads of acidic deposition for forest soils: is the current approach adequate? Ambio 25, 510-516.

Mitchell, M.J., Mayer, B., Bailey, S.W., Hornbeck, J.W., Alewell, C., Driscoll, C.T. and Likens, G.E., 2001. Use of stable isotope ratios for evaluating sulfur sources and losses at the Hubbard Brook Experimental Forest. Water Air Soil Pollut. 130, 75-86.

Moldan, F., Wright, R.F., Lofgrem, S., Forsius, M., Ruoho-Airola, T. and Skjelkvale, B.L., 2001. Long-term changes in acidification and recovery at nine calibrated catchments in Norway, Sweden and Finland. Hydrol. Earth. Syst. Sci., 5, 339350 .

Nilsson, J. and Grennfelt, P. (Eds.), 1988. Critical loads for sulphur and nitrogen. Report from a workshop held at Skokloster, Sweden 19-24 March, 1988, Miljorapport 1988:15, Nordic Council of Ministers, Copenhagen, Denmark.

Ouimet, R., Duschesne, D., Houle, D. and Arp, P.A., 2001. Critical Load and exceedances of acid deposition and associated forest growth in the northern hardwood and boreal coniferous forests in Quebec, Canada. Water Air Soil Pollut.: Focus 1, 119-134.

Park, S-O. and Lee, Y-H., 2001. Estimation of the maximum critical load for sulphur in south Korea. Water Air Soil Pollut. 130, 1145-1150.

Posch, M., de Smet, P.A.M., Hettelingh, J.P. and Downing, R.J., 2001. Modelling and mapping of critical thresholds in Europe. Status Report 2001, Coordination Center for Effects, Bilthoven, the Netherlands, RIVM Report No. 259101004, ISBN No. 969660-092-7.

Reynolds, B., Stevens, P.A., Hughes, S., Parkinson, J.A. and Weatherley, N.S., 1995. Stream chemistry impacts of conifer harvesting in Welsh catchments. Water Air Soil Pollut., 79, $147-170$

Skeffington, R.A. and Brown, D.J.A., 1992. Timescales of recovery from acidification: Implications of current knowledge for aquatic organisms. Environ. Pollut., 77, 227-234.

Tessier, A.J. and Horwitz, R.J., 1990. Influence of water chemistry on size structure of zooplankton assemblages. Can. J. Fish. Aquat. Sci., 47, 1937-1943.

Watmough, S.A. and Dillon, P.J., 2002c. Base cation and nitrogen budgets for seven catchments in central Ontario, 1983-1999. Forest Ecol. Manage. In press. 